Rahul B. HIREMATH

Ruth KATTUMURI

Bimlesh KUMAR

Vishwas N. KHATRI

Sharmila S. PATIL

\title{
An integrated networking approach for a sustainable textile sector in Solapur, India
}

This article addresses the environmental aspects of an unorganised textile sector with large-scale employment through a case study of the city of Solapur in the state of Maharashtra, India. Waste generated from the textile sector is causing serious problems such as changes to land and agricultural patterns, air quality, health and biodiversity. The methodology includes qualitative and quantitative data regarding the possible impact on climate, health, agriculture, biodiversity, water, air and soil. A detailed analysis was carried out through an extensive literature review. A possible solution in the form of a sustainable networking model for mitigating change is suggested. The sustainable model with integration of information and communication technology (ICT) will help achieve the desired development goals. The role of ICT is to channelise the supply chain, which can increase the efficiency and competitiveness of the sector.

Key words: climate change, environmental impacts, urban ecology, information and communication technology, India 


\section{Introduction}

Solapur is located on the southeast edge of the state of Maharashtra, India and lies entirely in the Bhima and Seena basins (Figure 1). The district is drained by the Bhima River. The Solapur district is geographically located between $17.10^{\circ}$ and $18.32^{\circ} \mathrm{N}$ and between $74.42^{\circ}$ and $76.15^{\circ} \mathrm{E}$ and is about $550 \mathrm{~m}$ above sea level. The district has eleven administrative divisions (Hindi talukas) and 1,150 villages. The mean temperature in the district ranges from $46^{\circ} \mathrm{C}(\max )$ to $9^{\circ} \mathrm{C}(\mathrm{min})$. The total net cultivated area is 1,069 ha and Solapur ranks last in rainfall in the state of Maharashtra with $545.4 \mathrm{~mm}$ annually. Solapur, with a population of 907,400 (2003), is the thirty-seventh most populous city in India and the eighth in the state of Maharashtra. Solapur is a fast-growing city in India in terms of geographical area in the decade from 1990 to 2000.

Solapur is best known for its textile products, including towels, bed linens and cotton blankets (Hindi chaddar). Today there are about 25,000 power looms employing about 100,000 workers. The textile manufacturing processes involve dyeing and bleaching activities, which cause major industrial pollution in the city and have major environmental impacts. The mass production of textiles in Solapur currently uses manufacturing process and chemicals and also consumes large quantities of water and electricity, which has a damaging effect on the environment. The effluent disposal facilities of these industries are very poor. The following are some effects of textile effluents (Hendrickson et al., 1995; Spiro, 1996; Müezzino, 1998):
- Pollution of water and soil in the surrounding environment due to discharges of large volumes of wastewater and sludge, which may contain high levels of toxic components such as metal-containing pigments or organic materials.

- The outdoor and indoor air are polluted due to directly released air pollutants such as combustor flue gases and emitted gases and vapours of some toxic or hazardous chemicals that may include known primary air pollutants (e.g., volatile organic compounds [VOCs] and free gaseous chlorine from aqueous chlorine compounds formed due to the use of hypo-chlorides), suspected photochemical precursors (e.g., chlorine radicals formed from chlorine gas molecules) and other suspected secondary air pollutants formed in the gas phase by the action of these precursors.

- Pollution caused by noise and dust emitted at various levels of the process.

- Large volumes of solid waste, which is a challenge for safe disposal using environmentally acceptable methods.

These emitted pollutants are released into the environment either continuously or intermittently. Table 1 summarises the wastes generated during textile manufacturing.

This paper reviews various textile industries' approaches adopted (see Figure 2) in order to evaluate models and methods for measuring the current impact of the textile industry on the environment, human health, biodiversity and climate in

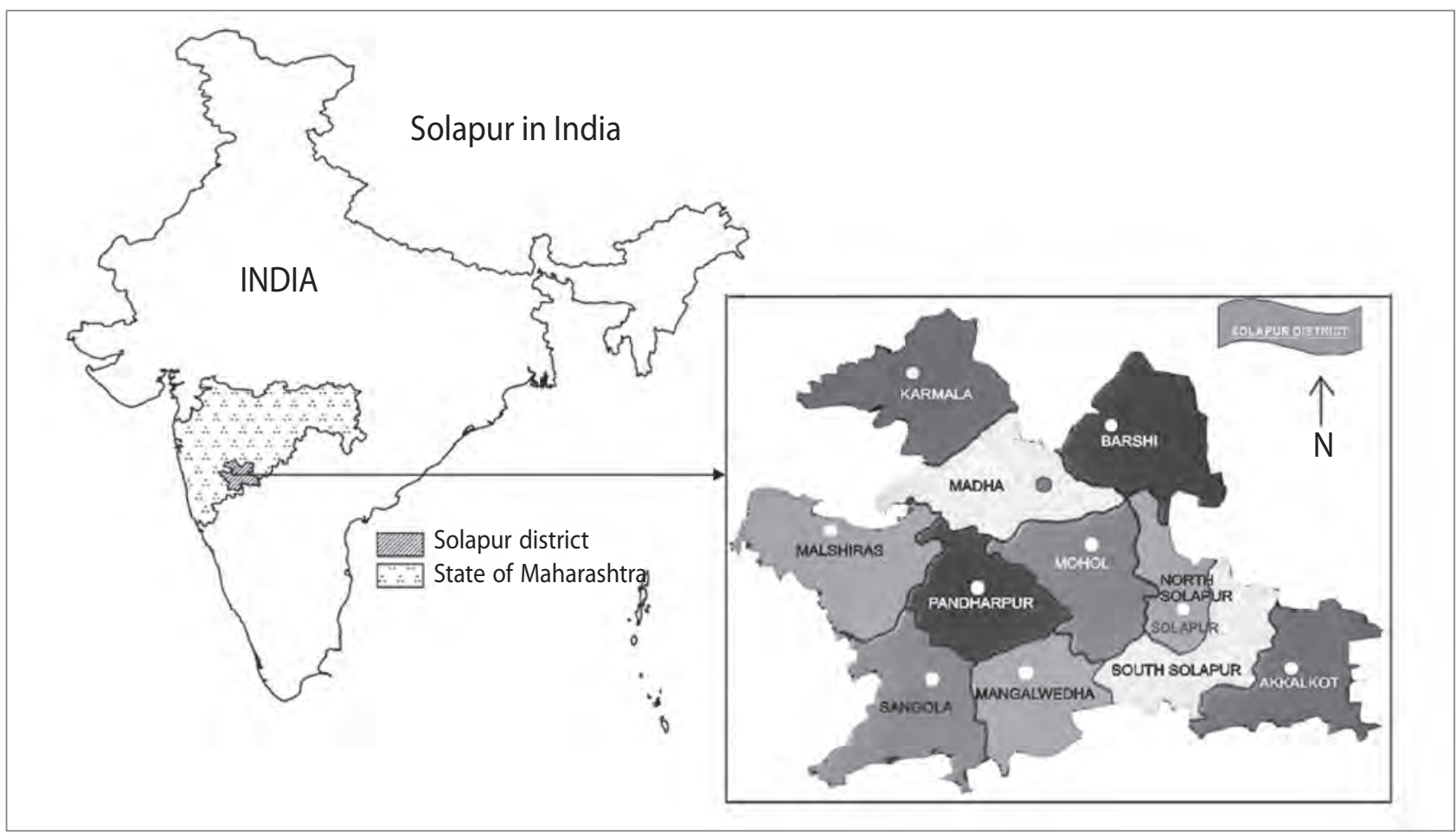

Figure 1: Location of the study area (source: Internet 1). 
Table 1: Summary of wastes generated during textile manufacturing

\begin{tabular}{|c|c|c|}
\hline Process & Source & Pollutants \\
\hline Energy production & Boiler emissions & Particulates, nitrous oxides $\left(\mathrm{NO}_{x}\right)$, sulphur dioxide $\left(\mathrm{SO}_{2}\right)$ \\
\hline Coating, drying and curing & High-temperature oven emissions & Volatile organic components (VOCs) \\
\hline Cotton-handling activities & $\begin{array}{l}\text { Emissions from preparation, carding, combing and } \\
\text { fabric manufacturing }\end{array}$ & Particulates \\
\hline Sizing & Emission from using sizing compound (gums, PVA) & Nitrogen oxides, sulphur oxide, carbon monoxide. \\
\hline Bleaching & Emission from using chlorine compound & Chlorine, chlorine dioxide \\
\hline Dyeing & Disperse dyeing using carriers, sulphur dyeing & Aniline dyeing carriers $\left(\mathrm{H}_{2} \mathrm{~S}\right)$, aniline vapours \\
\hline Printing & Emissions & Hydrocarbons, ammonia \\
\hline Finishing & Resin finishing, heat setting of synthetic fabrics & $\begin{array}{l}\text { Formaldehyde carriers, low molecular weight polymers, } \\
\text { lubricating oils }\end{array}$ \\
\hline Chemical storage & $\begin{array}{l}\text { Emissions from storage tanks for commodity and } \\
\text { chemicals }\end{array}$ & Volatile organic components (VOCs) \\
\hline Wastewater treatment & Emissions from treatment tanks and vessels & Volatile organic components, toxic emissions \\
\hline
\end{tabular}

Source: Internet 2.

Solapur. Based on this understanding, this research suggests a possible sustainable integrated model to mitigate the risks to the environment in the city.

\section{Methodology}

To assess the variation in the climate of the Solapur district, information was gathered regarding temperature, rainfall, precipitation and aridity from 1980 to 2010. This information was gathered from the Indian Meteorological Department, located within the city. The data are presented graphically so that changes in climate conditions can be clearly observed. Further relevant information regarding the impact of climate and the effect of the textile industry on this is supported with the help of environmental indicators such as change in air and water quality, crop patterns and bio diversity. An attempt is made to quantify degradation in air, water and soil quality. To assess health issues, data were collected on the number of patients admitted to the government hospital with respiratory tract infections. This can be further linked to possible air quality. A qualitative study of how the noise generated by looms in the textile industry affects workers' health was also carried out with the help of relevant literature. Finally, the impact of climate variation on the land and agriculture, socioeconomic conditions of the population and biodiversity are discussed at length.

\section{Climate impact assessment}

Climate change is caused by human induced greenhouse gas (GHG) emissions and the resulting increase in GHG con- centration in the atmosphere. Global efforts to address climate change include two basic responses: mitigation and adaptation (Sathaye \& Ravindranath, 1998). Mitigation is defined as human intervention to reduce the sources or enhance the sinks of GHGs. Actions that reduce net GHGs reduce the projected magnitude and rate of climate change and thereby lessen the pressure of climate change on natural and human systems. Therefore, mitigation actions are expected to delay and reduce damages caused by climate change, providing environmental and socioeconomic benefits (Ravindranath, 2007). The textile industry in Solapur requires various production processes. This is due to the wide variety of raw materials and treatment options available, which lead to a great variety of end products. The industry has high energy requirements throughout all stages of the production process. Some treatments such as melt spinning require refrigeration, and others such as dyeing, desizing and scouring need heat. Thus, energy consumption plays a central role in many key stages of the process. This shows that the textile business is involved with climate change by virtue of its considerable energy consumption. To meet its energy demand, the sector resorts to two distinct types of energy sources: indirect emission sources (electricity) and direct emission sources (natural gas, cogeneration and diesel fuel). Energy consumption is accompanied by a huge amount of effluent discharge, which is released into the environment. Reduction in GHG emissions and effluent discharge can be achieved through various means such as energy efficiency, cogeneration and treating effluent properly before discharging it. Such initiatives are totally absent in the textile industries of Solapur, causing considerable amount of pollution and leading to climate variation. This section provides some records of 


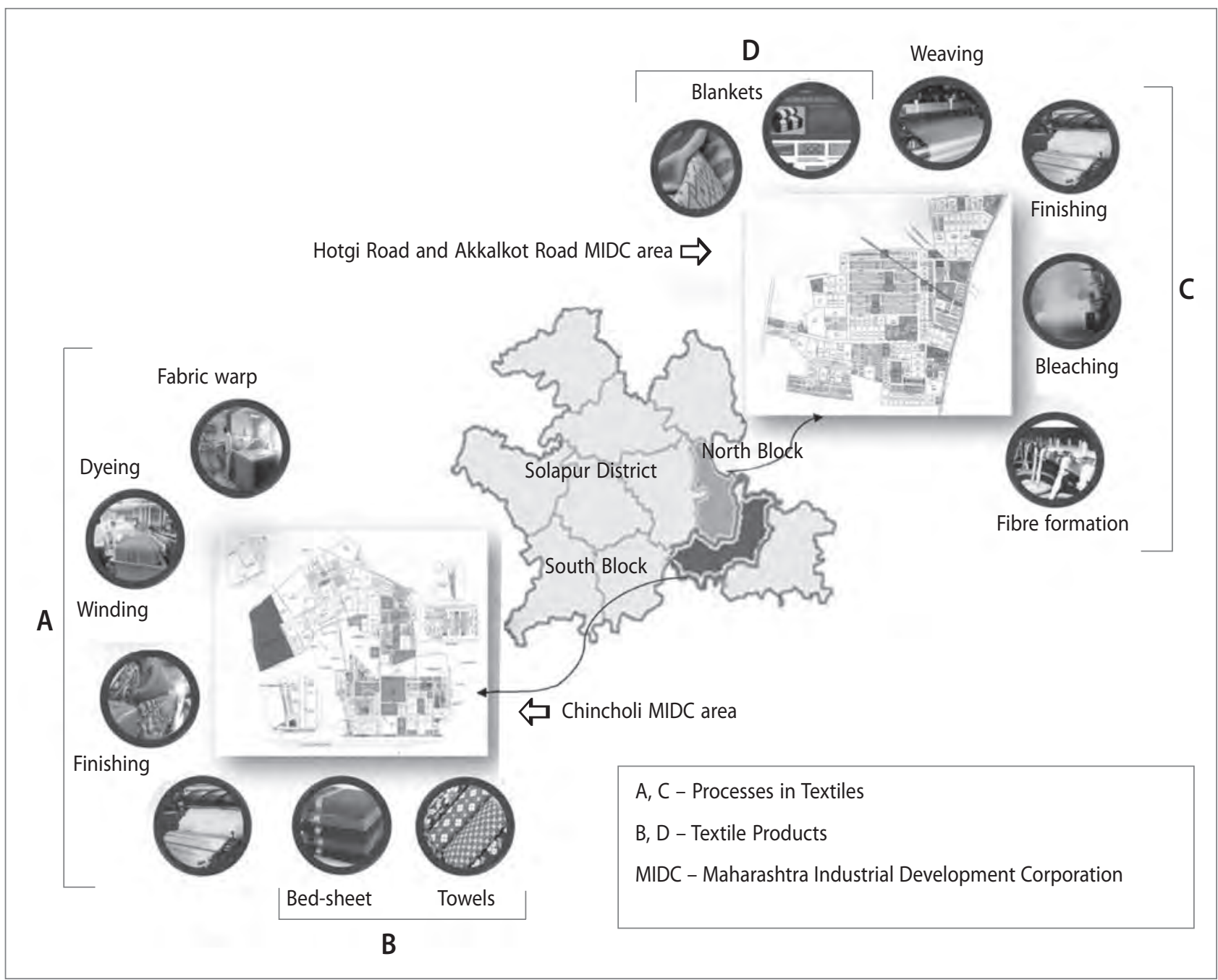

Figure 2: Processes and products of textile industries, Solapur (India) (illustration: Rahul B. Hiremath \& Bimlesh Kumar).

possible variability in temperature, precipitation, rainfall, wetlands, biodiversity and change in crop patterns, thus providing collateral evidence of climate change in the district.

Solapur has a subtropical monsoon-type climate. The southwest monsoon lasts from June to October and is responsible for about $87 \%$ of the annual rainfall (long-term normal $677.7 \mathrm{~mm}$ ). The winter season lasts from November to February and the summer extends from March to May. December is the coldest month, with the diurnal temperature varying between 15 and $30^{\circ} \mathrm{C}$. May is the hottest month, with the diurnal temperature ranging between 26 and $40{ }^{\circ} \mathrm{C}$. The air is humid during monsoon months; relative humidity ranges between 45 to $89 \%$ in the morning $(9: 30 \mathrm{am})$ and 17 to $70 \%$ in the evening $(5: 30 \mathrm{pm})$. The wind speed varies between $5.3 \mathrm{~km} / \mathrm{h}$ in December and $17.3 \mathrm{~km} / \mathrm{h}$ in June, averaging $10.3 \mathrm{~km} / \mathrm{h}$ annually. Figure 3 provides the data regarding average temperature, precipitation, rainfall and aridity from 1990 to 2010; the observational results show that variation can easily be identified, such as a decrease in precipitation and increase in temperature.
There is large variation in the rainfall pattern and aridity of the region, which strongly points to possible climate change.

Average annual precipitation is the average annual amount of precipitation for a location over a year. The precipitation for each month at a location is added and divided by twelve to obtain the average annual precipitation for a given location. Rainfall is one component of precipitation. Precipitation includes rainfall, snowfall, sleet, hail and so on. Aridity relates to a shortage of water resources. Aridity may be assessed on the basis of a) climate variables (index of aridity) or b) the number of days when the water balance favours plant growth (length of growing season). Projected changes in agriculture, land resources, water resources and biodiversity are probably inadequately estimated with climate change effects and these are examined in isolation. Characterisations of more complex relationships between climate change, land-use change and biodiversity, however, are currently limited by a lack of process understanding, data availability and inherent scenario uncertainties (Jacqueline \& Mark, 2009). 


\subsection{Environment impact indicators}

In recent years, environmental indicators have become a vital component of environmental impact assessments and "state of the environment" reporting. This enables informed decision-making for environmental management. Environmental impact indicators (EIIs) are measures that tell what is happening in the environment. Because the environment is very complex, indicators provide a more practical and economical way to track the state of the environment. An environmental indicator is a numerical value that helps to provide insight into the state of the environment or human health (Ditor et al., 2001). Indicators are developed based on quantitative measurements or statistics of environmental condition that are tracked over time.

However, in many studies no formal selection criteria are mentioned and when selection criteria are used they are typically applied to indicators individually and there is a need to improve the scientific basis of the selection process for the indicators used. This is especially true for the textile industry, in which small- and medium-sized enterprises (SMEs) predominate. Sector-specific EIIs for products and their surroundings are particularly underdeveloped. Due to the difficulty in selecting individual indicators, in this paper we have created a conceptual framework for EIIs for the textile sector in Solapur that applies the concept of a causal network focusing on the interrelation of various indicators. The concept of networks can facilitate identification of the most relevant indicators for a specific domain (the textile sector), problem and location (Solapur), leading to an indicator set that is simultaneously transparent, efficient and powerful in its ability to assess the state of the environment. The following section explains the effects of waste generated in the textile sector and its possible impact on quality of air, water and biodiversity.

\subsubsection{Impact on air quality}

Air pollutants are generated by fossil fuels and other kinds of fuel-fired combustors due to their exhausts and/or a variety of chemicals used for production (this is seen in cotton textile manufacturing operations). Excessive use of chemicals can be
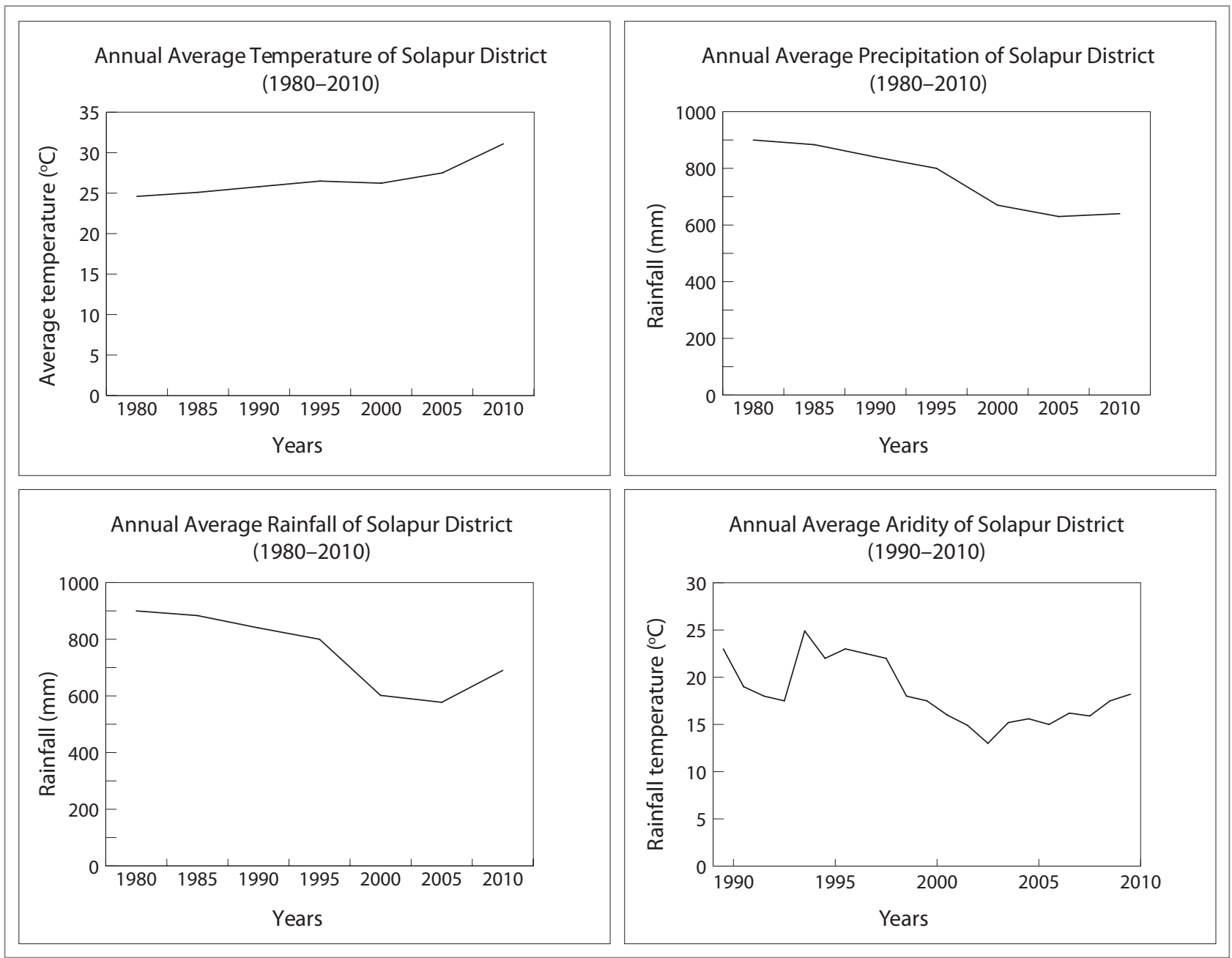

Figure 3: Average temperature, precipitation, rainfall and aridity data for the Solapur District (1980-2010; source: District Unit Solapur, 2012a) 
stopped or minimised by replacing them or by optimising the production processes. Air pollutant emission sources in the textile sector can be divided into two categories: combustion flue gases and process emissions into both indoor and outdoor air (Müezzino, 1998). Process emissions may be in the form of direct emissions into the air through ducts or fugitive emissions and leaks into both outdoor and indoor air. A paper on air pollution resulting from cotton textile manufacturing operations (Müezzino, 1998) discusses some quantitative examples for evaluating the risks to the environment. It studied impacts on the environment such as direct discharges into the outdoor air and the workplace atmosphere. It states that further research and development studies for minimising the impacts on local and global air quality due to cotton textile production facilities is of the utmost important. Another study (Velavan et al., 2009) states that growth of the Indian textile industry has resulted in increased $\mathrm{CO}_{2}$ emissions and other related pollution. $\mathrm{CO}_{2}$ emissions from the Indian textile sector (SMI) were estimated according to the guidelines by the Intergovernmental Panel on Climate Change (IPCC; Velavan et al., 2009).

The economy of Solapur depends on small- and medium-sized textile and sugar industries. The district has a climate favourable for the growth of sugarcane (sugarcane is one of the important cash crops of the district), due to which the sugar industry is flourishing. The district has nearly twenty-two sugar factories, which are well connected by roads. Sugarcane is harvested twice in a year (for nearly two to three months). Due to the lack of proper public transport facilities near the rural areas in some cases and the unaffordable cost of transportation in others, the cane is transported from its source to the processing plants by oxcarts and tractors, which is quite detrimental to the roads. Such operation leads to the degradation of road quality, requiring periodic maintenance. The poor quality of roads in some parts of the district combined with heavy vehicular traffic releases a large amount of dust particles from the road along with vehicular emissions into the atmosphere. Because Solapur is a dry region, these pollutants remain suspended in the atmosphere for a long time, leading to poor air quality. To make the problem worse, the proximity of various textile industries in the district contributes additional pollutants in the form of cotton particles, which float along with the air. The combined effect of pollution generated by industry and traffic is very injurious to health, and respiratory syndromes are common in the district.

Ambient air-quality monitoring at the city level was conducted by Central Pollution Control Board (CPCB) and Ministry of Environment and Forests (MoEF), India. The data show that Solapur is among the seventeen most polluted cities in India (Agra, Ahmedabad, Bangalore, Chennai, Delhi, Faridabad, Hyderabad, Jharia, Jodhpur, Kanpur, Kolkata, Lucknow, Mumbai, Patna, Pune, Solapur and Varanasi; Central Pollution Control Board, 2012). Following this report, the Maharashtra Pollution Control Board (MPCB) has been monitoring the ambient air quality in Solapur monthly at two locations (at the Ashok Chowk, WIT campus and at Saat Rasta in Solapur) since 2000 under the National Ambient Air Quality Monitoring Program (NAAQM). The air-quality parameters included (Table 2) are sulphur dioxide $\left(\mathrm{SO}_{2}\right)$, nitrogen oxides $\left(\mathrm{NO}_{\mathrm{x}}\right)$, suspended particulate matter (SPM) and respirable suspended particulate matter (RSPM).

Table 2 shows that the SPM (higher) and RSPM (slightly higher) values exceed the prescribed limits mentioned in NAAQM at both monitoring locations. The possible reasons for high levels of particulate matter (dust, chemical vapours and other secondary air pollutants) could be due to diesel generators used to compensate for the inconsistent grid supply, boilers, floating dust, re-suspension of the dust due to arid and dry climatic conditions prevailing in the city and lack of adequate public transport within the city.

\subsubsection{Status of public health}

The health of people in the vicinity has also been affected. The Shri Chhatrapati Shivaji Medical College (SCSM) and general hospital in Solapur conducted a survey on the impact of air pollution on the health of population within the Solapur city limits. The figures on the health status of the local population are based on secondary information contributed by the

Table 2: Annual average values of sulphur dioxide $\left(\mathrm{SO}_{2}\right)$, nitrogen oxides $\left(\mathrm{NO}_{\mathrm{x}}\right)$, suspended particulate matter (SPM) and respirable suspended particulate matter (RSPM) from 2006 to 2010 at the WIT Campus, Solapur, India

\begin{tabular}{lllll}
\hline Year & $\mathrm{SO}_{2}$ & $\mathrm{NO}_{2}$ & $\mathrm{RSPM}$ & $\mathrm{SPM}$ \\
\hline 2006 & 15.5 & 34.75 & 102 & 322.75 \\
\hline 2007 & 16.16 & 34.33 & 83.52 & 302.33 \\
\hline 2008 & 17.08 & 34.15 & 78.5 & 293.41 \\
\hline 2009 & 16.05 & 34.425 & 102.93 & 280.15 \\
\hline 2010 & 16.62 & 35.17 & 103.04 & 272.62 \\
\hline Limit & 80.00 & 80.00 & 100.00 & 200.00 \\
\hline
\end{tabular}

Source: Central Pollution Control Board (2012) 
Table 3: Number of patients with respiratory tract infections admitted to the SCSM general hospital in Solapur (2001-2010)

\begin{tabular}{|c|c|c|c|c|c|c|c|c|c|c|}
\hline Diseases & 2001 & 2002 & 2003 & 2004 & 2005 & 2006 & 2007 & 2008 & 2009 & 2010 \\
\hline Pulmonary tuberculosis & 770 & 675 & 754 & 703 & 759 & 856 & 710 & 840 & 879 & 910 \\
\hline $\begin{array}{l}\text { Malignant neoplasm of the lip, oral cavity } \\
\text { and pharynx }\end{array}$ & 2 & 56 & 44 & 46 & 48 & 47 & 51 & 57 & 64 & 71 \\
\hline $\begin{array}{l}\text { All other diseases of the } \\
\text { upper respiratory tract }\end{array}$ & 219 & 191 & 239 & 139 & 165 & 191 & 187 & 210 & 215 & 221 \\
\hline $\begin{array}{l}\text { Acute bronchitis and } \\
\text { bronchiolitis }\end{array}$ & 23 & 54 & 121 & 82 & 96 & 136 & 141 & 124 & 137 & 157 \\
\hline Pneumonia & 449 & 351 & 423 & 325 & 315 & 329 & 119 & 278 & 302 & 368 \\
\hline $\begin{array}{l}\text { Bronchitis, chronic/unspecified emphyse- } \\
\text { ma and asthma }\end{array}$ & 410 & 426 & 500 & 446 & 315 & 291 & 278 & 383 & 457 & 468 \\
\hline Pleurisy & 1 & 9 & 4 & 6 & 5 & 10 & 4 & 11 & 15 & 17 \\
\hline $\begin{array}{l}\text { All other diseases of the } \\
\text { respiratory system }\end{array}$ & 42 & 86 & 116 & 101 & 099 & 109 & 60 & 78 & 89 & 124 \\
\hline Total & 1,916 & 1,848 & 2,201 & 1,848 & 1,802 & 1,969 & 1,550 & 1,981 & 2,158 & 2,336 \\
\hline
\end{tabular}

Source: District Unit Solapur (2012b)

district and municipal health authorities within the Solapur municipal limits (Table 3). The results of this survey revealed that the number of patients with respiratory tract infections admitted to the SCSM general hospital in Solapur (from 2001 to 2010 ) is increasing.

If precautions are taken, the air pollution potential of cotton textile manufacturing can be minimised; in other words, control would be possible through source reduction and material balances around the production steps. Further research on indoor air quality in Solapur would be valuable for better understanding. Air quality considerations within and surrounding areas affected by direct (regulated) or indirect (workplace air discharge through ducts) air pollution would cover the prima-

Table 4: Characteristics of effluents in the Solapur industrial area

\begin{tabular}{ll}
\hline Parameters & Results \\
\hline Colour & Bluish \\
\hline $\mathrm{pH}$ & 6.74 \\
\hline Electrical conductivity & $151.6 \mathrm{mS} / \mathrm{cm}$ \\
\hline Total dissolved solids & $97024 \mathrm{mg} / \mathrm{L}$ \\
\hline Alkalinity & $1170 \mathrm{mg} / \mathrm{L}$ \\
\hline Acidity & $355 \mathrm{mg} / \mathrm{L}$ \\
\hline Dissolved oxygen & $1.2 \mathrm{mg} / \mathrm{L}$ \\
\hline Hardness & $542 \mathrm{mg} / \mathrm{L}$ \\
\hline Calcium & $132.26 \mathrm{mg} / \mathrm{L}$ \\
\hline Magnesium & $51.66 \mathrm{mg} / \mathrm{L}$ \\
\hline Chloride & $1904.22 \mathrm{mg} / \mathrm{L}$ \\
\hline Sodium & $1252.56 \mathrm{mg} / \mathrm{L}$ \\
\hline Potassium & $162.76 \mathrm{mg} / \mathrm{L}$ \\
\hline Sulphate & $79.6 \mathrm{mg} / \mathrm{L}$ \\
\hline
\end{tabular}

Source: Panaskar \& Pawar (2011) ry release of dust and chemical vapours from the textile plants as well as the potential secondary air pollutants formed later in the atmosphere. This would help in controlling the situation and developing waste-minimisation techniques to reduce the use of such chemicals whenever and wherever possible.

\subsubsection{Impact on water}

Textile manufacturing processes involve dyeing and bleaching activities, and these are the major sources of industrial pollution in the city. The effluent disposal facilities of these industries are very poor. Wastewater discharges are unavoidable in the industrial process, which leads to water and soil pollution. Bodies of water and the soil are becoming major sinks for industrial pollutants. These pollutants affect ecosystems and agricultural land. Textile mills' effluent discharge from various units in the city contains various types of pollutants such as dyes, solids and traces of heavy metals. These released pollutants directly or indirectly lead to the pollution of surface water, groundwater and soil. Table 4 shows the characteristics of effluent in the Solapur industrial area and Table 5 shows the composition and nature of various effluents in various phases of the textile industry.

A recent paper (Naik et al., 2008) describes the impact of urbanisation and industrialisation on the groundwater regime in the fast-growing city of Solapur, placing special emphasis on the management of the present and ultimate demand for water in the year 2020. Another study in the Environment Impact Assessment (EIA) report (2010) showed that the increased use of pesticides, fertilisers and industrial wastewater with intensified irrigation has led to groundwater pollution. The effect of Solapur textile effluents on the germination of various seeds such as Sorghum vulgare (sorghum), Vigna aconitifolia (moth 
Table 5: Composition and nature of various effluents in various phases of the textile industry

\begin{tabular}{lll}
\hline Process & Composition & Nature \\
\hline Sizing & Starch, waxes, carboxymethyl cellulose, polyvinyl alcohol & $\begin{array}{l}\text { High biochemical oxygen demand (BOD) and chemical } \\
\text { oxygen demand (COD) }\end{array}$ \\
\hline Desizing & $\begin{array}{l}\text { Starch, glucose, carboxymethyl cellulose, polyvinyl alcohol, fats, } \\
\text { waxes }\end{array}$ & High BOD, COD, suspended solids, dissolved solids \\
\hline Scouring & $\begin{array}{l}\text { Caustic soda, waxes, grease, soda ash, sodium silicate, fibres, } \\
\text { surfactants, sodium phosphate }\end{array}$ & Dark coloured, high pH, high COD, dissolved solids \\
\hline Bleaching & $\begin{array}{l}\text { Hypochlorite, chlorine, caustic soda, hydrogen peroxide, acids, } \\
\text { surfactants, sodium silicate, sodium phosphate }\end{array}$ & Alkaline, suspended solids \\
\hline Mercerising & Caustic soda & High pH, low COD, high dissolved solids \\
\hline Dyeing & Various dyes, mordants, reducing agents, acetic acid, soap & $\begin{array}{l}\text { Strongly coloured, high COD, dissolved solids, low } \\
\text { suspended } \\
\text { solids, heavy metals }\end{array}$ \\
\hline Printing & Pastes, starch, gums, oil, mordants, acids, soaps & $\begin{array}{l}\text { Highly-coloured, high COD, oily } \\
\text { appearance, suspended solids }\end{array}$ \\
\hline Finishing & Inorganic salts, toxic compounds & Slightly alkaline, low BOD \\
\hline
\end{tabular}

Source: Cooper (1978)

bean), Vigna unguiculata (cow pea) and Pisum sativum (pea) has been studied (Panaskar \& Pawar, 2011); these grow abundantly in nearby areas and are much in demand as food species. The effects were examined in relation to various concentrations of effluents and various parameters such as seed germination, mean root length of germinated seedlings, plumule germination, mean plumule length of germinated seedlings, disease (fungus) causes in germinated seedlings and other morphological characters. The results showed that an increase in concentration (20-100\%) of textile mill effluent for irrigation adversely affects the germination of seeds. The results showed that although pure textile mill effluent could not be used to germinate seeds, a dilution (20\%) of effluent concentration may be used. The better growth of all the seeds at $20 \%$ effluent concentration may be due to the growth-promoting effect of nitrogen and other mineral elements in the effluent.

\subsubsection{Noise pollution}

The most significant risk related to the textile industry is overexposure to sound from loom operation, which depends on the time of exposure, noise intensity and frequency, which can reduce the hearing threshold temporarily or, in the worst cases, permanently. There are multiple recorded cases of workers' physical and psychological disorders caused by exposure to excessive noise pollution (Giardino \& Durkt, 1996). Many other effects are caused by extended exposure to noise pollution, including agitation, constant weariness, disorientation, headaches, vertigo, hypertension, cardioarrythmia and nervous and psychic disorders (Van Kempen et al., 2002). Diseases such as measles, mumps, scarlet fever, diphtheria, whooping cough, influenza and certain other viral infections can lead to sensorineural hearing loss. The processes of these diseases can have a toxic effect on the sensitive nerve endings in the cochlea. Infections of the cerebrospinal fluid such as meningitis can also cause damage to the cochlea. Tumours near the auditory nerve can cause sensorineural hearing loss due to pressure on the nerve (Newby, 1972). A study (Bedi, 2006) of two textile plants in the northern Indian state of Punjab involving 112 workers results showed that high noise levels are found in the textile process from fibre to fabric, clattering of gear wheels, the high-speed whine of twisting, spinning machinery and the noise of weaving machines. Another paper (Hannak \& Balakrishnan, 2005) states that noise sources in any industrial process may be due to propagation through the air (air-borne noise), propagation through solids (structure-borne noise), diffraction at the machinery boundaries, or reflection from the floor, wall, ceiling and machinery surfaces. Noise-reducing measures would include installing screens and sound baffles on fans, regular maintenance of machinery, fitting anti-vibration mounts on machines and fitting walls with sound-absorbing materials. The noise-pollution problem can be extended outside the plant premises through the diesel generator sets used as an alternative to grid electricity, and vehicles used for loading, unloading (raw materials) and carrying finished products to different locations. An EIA report (2010) clearly explains the noise pollution issue; the report studies noise levels at three locations on the outskirts of Solapur (Ekrukh, Haglur \& Banegaon). The study showed that the noise level is in the range of 50.0 to $54.3 \mathrm{~dB}$.

\section{A possible solution}

A possible solution would be adopting eco-friendly and sustainable textile methods with the help of Information and 
Communication Technology (ICT). The Indian eco-friendly textiles market is clearly in a nascent stage. An overview of the market typically shows the absence of any significant player selling products with an eco-friendly tag. A retail boom has shown that there is large segment of aware people, especially in the middle class, who have sufficient disposable income and are willing to experiment (Fletcher, 2008). Consequently, there is also a lot of interest among some larger players in using a "green" tag. Thus there is a large scope for the textile industries to expand their market by adapting market needs through ICT. ICT integrates telecommunications with computers, middleware and necessary software, storage and audio-visual systems, which enable users to create, access, store, transmit and manipulate information. The EICTA (European ICT Industry Association) has found that ICT improves the business environment for the European information and communications technology and consumer electronics (ICT \& CE) sector and promotes the industry's contribution to economic growth and social progress in the European Union. The report on ICT applications can be found on various websites; for example, Nathan Associates and the European Investment Bank.

\subsection{ICT in textile industries}

ICT as a technology can improve business practices and increase the efficiency and competitiveness of textile industries. It is the main driver that shifts value along the value chain, enabling new business models, disaggregating production chains and creating new opportunities for textile industries in the global supply chain (Dimelis \& Papaioannou, 2011). ICT developments can be used as the medium in the Solapur textile sector to achieve combined economic growth, social de- velopment and environment protection. ICT has commercial incentives to support energy efficiency, reduce costs, improve management services, reduce delays and promote corporate social responsibility, which improves the brand image and thus creates new market opportunities. ICT includes communication devices or applications, which are radio, television, mobile phones, computers, networks, hardware and software, as well as the various services and applications associated with them, such as videoconferencing and distance learning. Among other things, ICT involvement in the textile industries supports obtaining information on demand, reducing procurement time, sharing proper information among industries and managing data centrally. The process of creating finished textile products from raw materials consists of steps such as spinning, weaving, knitting, dyeing and finishing. ICT can decrease the amount of time to complete the production process. Industry can use the concept of e-retailing and e-commerce for direct selling of product with effective presentation and sampling to consumers through the Internet. Table 6 summaries the role of ICT in various phases of the textile industry.

\subsection{Integrated sustainable model of networking}

Large market-related opportunities exist in textile sectors with eco labelling and sustainability due to the rapidly growing retail market, the growing textile and clothing market, and young and aware consumers. However, there are also challenges at a much larger or macro level, especially related to common understanding and awareness of the advantage of implementing sustainability techniques in the industry. The Solapur district can tap the opportunity for producing sustainable clothing with an eco label. This effort is only possible through a coor-

Table 6: Phases and functions of the textile industry with ICT solutions

\begin{tabular}{|c|c|c|c|}
\hline \multirow[t]{2}{*}{ Textile industry phases } & \multirow[t]{2}{*}{ Functions } & \multicolumn{2}{|l|}{ Role of ICT } \\
\hline & & Techniques & Software \\
\hline $\begin{array}{l}\text { Purchasing raw materials, material } \\
\text { management, sales, costing, ware- } \\
\text { housing and accounts }\end{array}$ & $\begin{array}{l}\text { Data analysis, accounting, } \\
\text { sales orders, inventory, } \\
\text { financial reports }\end{array}$ & Automation software & $\begin{array}{l}\text { MS-Office, Tally, Techage textile } \\
\text { management system, PRLog }\end{array}$ \\
\hline Design & $\begin{array}{l}\text { Design, drawing, punching, } \\
\text { colour filling }\end{array}$ & Computer Aided Design (CAD) & $\begin{array}{l}\text { DigiFab, jacqCAD, Lectra, } \\
\text { Gerber's, Texpro, Techmen }\end{array}$ \\
\hline Spinning and weaving & $\begin{array}{l}\text { Cotton mixing, carding, } \\
\text { wrapping, yarn production, } \\
\text { winding }\end{array}$ & $\begin{array}{l}\text { The textile network, LAN hardware, } \\
\text { sensors }\end{array}$ & $\begin{array}{l}\text { LAN (client-server model) soft- } \\
\text { ware }\end{array}$ \\
\hline Dyeing and printing & $\begin{array}{l}\text { Doubling, bleaching, } \\
\text { dyeing }\end{array}$ & $\begin{array}{l}\text { Various dyeing and printing tech- } \\
\text { niques using software }\end{array}$ & $\begin{array}{l}\text { Print Pro v3.0, YX Print Platinium, } \\
\text { DTG RIP Pro }\end{array}$ \\
\hline Lay planners and cutting & Planning, cutting & Computerised cutting table & Lectra, Gerber, Assyst Bulmer, etc. \\
\hline Consumer & Display, purchase order & Tele shopping, online shopping & Company websites \\
\hline Supply chain & $\begin{array}{l}\text { Transportation of finished } \\
\text { product to consumer }\end{array}$ & $\begin{array}{l}\text { End-to-end transportation automa- } \\
\text { tion and supply chain management }\end{array}$ & $\begin{array}{l}\text { Import Studio, Warehouse Explo- } \\
\text { rer, Global Tracker }\end{array}$ \\
\hline
\end{tabular}




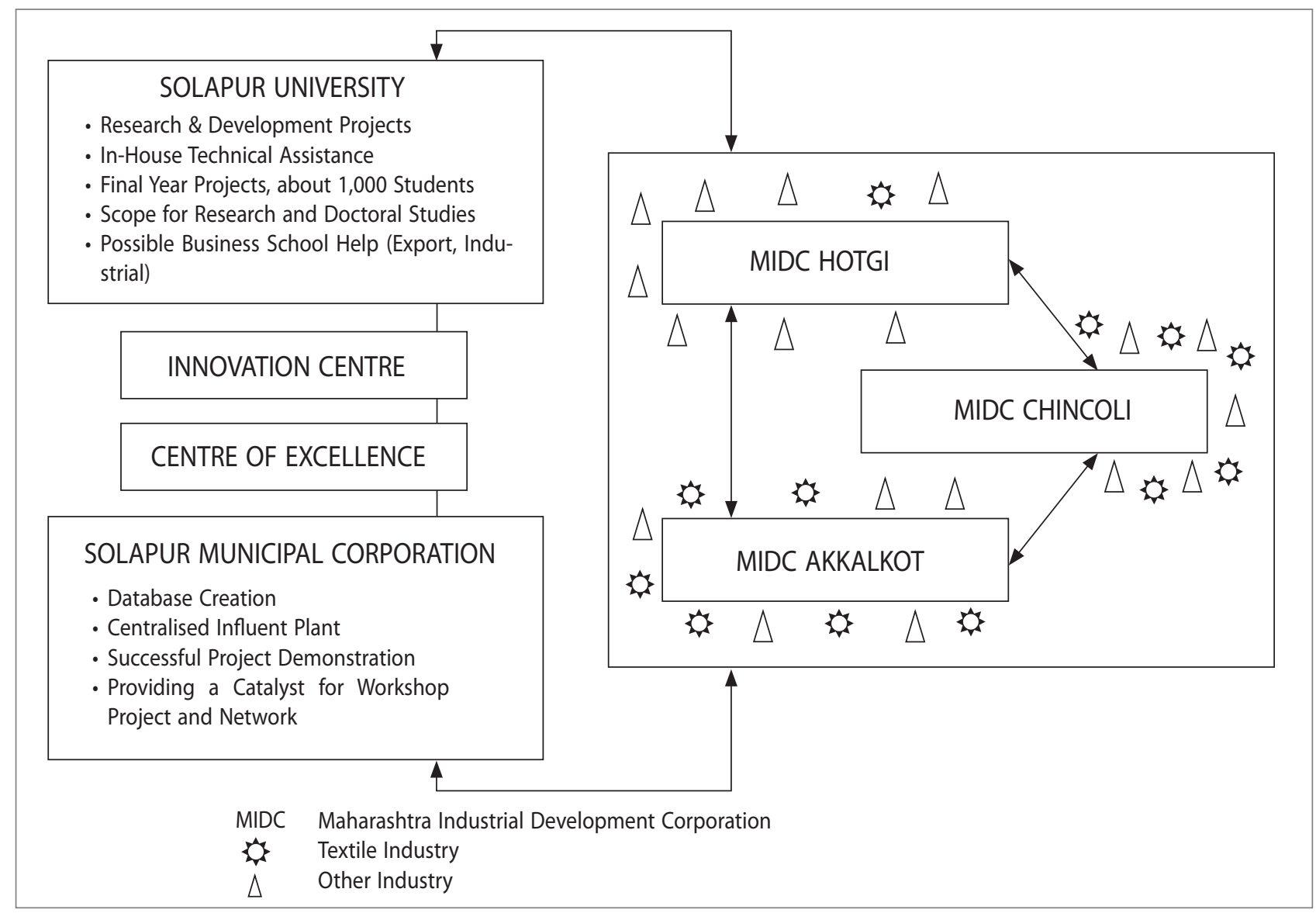

Figure 4: Integrated sustainable model of networking for Solapur (illustration: Rahul B. Hiremath \& Bimlesh Kumar).

dinated effort by textile industries, universities (academicians) and the Solapur municipal corporation (SMC) through providing feasible policies for its promotion. Such a venture will aid the economic development of the district; to make this happen, there is a need for an integrated sustainable model of networking. Maharashtra Industrial Development Corporations (MIDC) has developed three zones for industrial development (on Akkalkoat, Hotgi and Chincholi roads), which are under the jurisdiction of the SMC. The district has a new university named Solapur University that was established in 2004. The university is home for many engineering and management institutions, and is the knowledge hub of thousands of students graduating every year. A sustainable integrated model is proposed by networking SMC, Solapur University and textile industries in order to achieve the desired development goals. This model will operate with the possible establishment of a centre for excellence and innovation centre at the base and using local knowledge resources to sustain the process. The mutual cooperation between industry, the SMC and the university can create research and development projects, improve the market share for the industry, reduce the environmental burden and improve the economic development of the district. The interfaces thus enabled can be developed to disseminate information for various plans and services directly to trade and industry. These initiatives can facilitate greater efficiency, trans- parency and responsiveness towards industrial development. ICT will support networking, development and maintaining infrastructure and services. Figure 4 shows the integrated sustainable model of networking for Solapur.

The textile sector has great potential to strengthen the district's economic growth. Some of the positive aspects of this integrated sustainable model of networking are that it would act as one of the major sources of employment generation, increase the living standard of the local community and help increase production capacity and exports, thereby contributing to the district's economy. It would also assist in environmentally benign techniques, build a platform for industry, establish collaborative research and consulting, and aid transportation.

\section{Conclusion}

The study provides an overview of the textile and clothing industry in a city that is one of the biggest sectors for employment and exports. There is a problem in the city because the effluent disposal facilities of these industries are very poor, a fact that has created environmental, health and social problems. To counteract this effect, this study reviews textile industry approaches and evaluates models and methods for 
measuring the impact of the textile industry on the environment, human health, biodiversity and the climate. There is therefore a need to develop an integrated sustainable model of networking for climate change mitigation using an adaptation approach related to the environment, health, safety and cleaner production, which assists in building a local knowledge base to sustain this process. The proposed integrated sustainable model of networking provides a possible solution at the district level, which can be adopted by the state in the near future. The key finding is that environmentally sustainable industrial development is important for preserving the long-term interests of communities that depend on this industry as well as the communities whose livelihood is affected because of pollution. Promoting an integrated sustainable model between industry, SMC and the university will advance sustainable development in the district. To achieve a significant scale of operation at the district and state levels, agencies such as state government, the district municipal corporation and textile owners should provide investment capital and incremental funding in order to achieve significant viable and visible change. Funding and policy support are necessary for implementing such projects at a decentralised level (the district and administrative divisions), which can play a key role in a sustainable district plan. Models with a bottom-up approach can easily be expanded and implemented at the state and national levels, thus creating economic prosperity.

Rahul B. Hiremath

Subir Chowdhury Research Fellow, Asia Research Centre, London School of Economics and Political Science, London, United Kingdom Indian Institute of Science, Bangalore, India

E-mail: rahulhiremath@gmail.com

Ruth Kattumuri

Asia Research Centre and India Observatory, London School of Economics and Political Science, London, United Kingdom

E-mail: r.kattumuri@lse.ac.uk

\section{Bimlesh Kumar}

Civil Engineering, Indian Institute of Technology, Guwahati, India

E-mail: bimk@iitg.ernet.in

Vishwas N. Khatri

NIT Hamirpur, India

E-mail: vishwasnkhatri@gmail.com

Sharmila S. Patil

Information Technology Department, WIT, Solapur, India

E-mail: shrmlkrp@gmail.com

\section{Acknowledgement}

This paper would not have been possible without the support of the Subir Chowdhury Fellowship at the LSE Asia Research Centre, Arvind R. Doshi (Chairman, SAPDJ Pathashala, Solapur), Ranjeet H. Gandhi, (Secretary and Trustee of SAPDJ Pathashala, Solapur) and S. A. Halkude, (Principal WIT, Solapur).

\section{References}

Bedi, R. (2006) Evaluation of occupational environment in two textile plants in northern India with specific reference to noise. Industrial Health, 44(1), pp. 112-116. DOI: 10.2486/indhealth.44.112

Central Pollution Control Board (2012) Air quality data. Available at: http://cpcb.nic.in (accessed 6 Jun. 2012).

Cooper, S. G. (1978) The textile industry: Environmental control and energy conservation. Perk Ridge, NJ, Noyes Data Corporation.

Dimelis, S. \& Sotiris, K. P. (2011) ICT growth effects at the industry level: A comparison between the U.S. and the EU. Information Economics and Policy, 23(1), pp. 37-50. DOI: 10.1016/j.infoecopol.2010.03.004

District Unit Solapur (2012a) Average temperature, precipitation, rainfall and aridity data for Solapur District. Available at: http://solapur.gov.in (accessed 6 Jun. 2012).

District Unit Solapur (2012b) Patients with respiratory tract infections admitted in SCSM general hospital Solapur. Available at: http://www. solapur.gov.in (accessed 6 Jun. 2012).

Ditor, M., O'Farrell, D., Bond, W. \& Engeland, J. (2001) Guidelines for the development of sustainability indicators. Gatineau, QC, Environment Canada \& Canada Mortgage and Housing Corporation.

Fletcher, K. (2008) Sustainable fashion and textiles: Design journeys. London, Earthscan.

Giardino, D. A. \& Durkt, G. (1996) Evaluation of muff-type hearing protectors as used in a working environment. American Industrial Hygiene Association Journal, 57(3), pp. 264-271. DOI: 10.1080/15428119691014990

Hannak, S. \& Balakrishnan, K. (2005) Job hazards profiling and workplace improvements in SMES - experiences from India. Safety Science Monitor, 9(1), pp. 1-4.

Hendrickson, J. B., Cram, D. J. \& Hammond, G. S. (1995) Organic chemistry. New York, McGraw-Hill.

Internet 1: www.mapsofindia.com (accessed 6 Jun. 2012)

Internet 2: http://www.fibre2fashion.com/industry-article/16/1523/ tables.html (accessed 6 Jun. 2012).

Müezzino, A. (1998) Air pollutant emission potentials of cotton textile manufacturing industry. Journal of Cleaner Production, 6(3-4), pp. 339347. DOI: 10.1016/S0959-6526(98)00013-4

Naik P. K., Tambe J. A., Dehury B. N. \& Tiwari A. N. (2008) Impact of urbanization on the groundwater regime in a fast growing city in central India. Environmental Monitoring and Assessment, 146(1-3), pp. 339-373. DOI: 10.1007/s10661-007-0084-6

Newby, H. A. (1972) Audiology. Englewood Cliffs, NJ, Prentice Hall.

Panaskar, D. B. \& Pawar, R. S. (2011) Effect of textile mill effluent on growth of Sorghum vulgare (Jowar) and Vigna aconitifolia (Matki) seedlings. Indian Journal of Science and Technology, 4(3), pp. 273-278.

Ravindranath, N. H. (2007) Mitigation and adaptation synergy in forest sector. Mitigation and Adaptation Strategies for Global Change, 12(5), pp. 843-853. DOI: 10.1007/s11027-007-9102-9

Sathaye, J. A. \& Ravindranath, N. H. (1998) Climate change mitigation in the energy and forestry sectors of developing countries. Annual Review of Energy \& Environment, 23, pp. 387-437. DOI: 10.1146/annurev. energy.23.1.387

Spiro, T. G. \& Stigliani, W. M. (1996) Chemistry for the environment. Upper Saddle River, NJ, Prentice Hall. 
Environment Impact Assessment (2010) Ekrukh lift irrigation scheme at Haglur, Tal. North Solapur. Solapur, Maharashtra Krishna Valley Development Corporation.

Van Kempen, E. E., Kruize, H., Boshuizen, H. C., Ameling, C. B., Staatsen B. A. \& de Hollander, A. E. (2002) The association between noise exposure and blood pressure and ischemic heart disease: A meta-analysis. Environmental Health Perspectives, 110(3), pp. 307-317. DOI: 10.1289/ ehp.02110307

Velavan, R., Rudramoorthy, R. \& Balachandran, S. (2009) $\mathrm{CO}_{2}$ emission reduction opportunities for small and medium scale textile sector in India. Journal of Scientific \& Industrial Research, 68(7), pp. 630-633. 